\title{
ANALYSIS OF THE INFLUENCE OF SERVICE QUALITY ON CUSTOMER SATISFACTION
}

\author{
Rudi Triadi Yuliarto \\ Sekolah Tinggi Ilmu Ekonomi Boedi Oetomo, Pontianak, Indonesia \\ email: syifapga@gmail.com
}

\begin{abstract}
The purpose of this study was to determine the effect of service quality on customer satisfaction at the Pontianak Class II Port Authority and Harbormaster Office. The population used in this study were 81 people (census). This study uses multiple linear regression analysis, with SPSS statistical software. Service quality variables, with the dimensions of physical evidence (tangibles), and assurance, each have a positive and significant effect on customer satisfaction, then the reliability, responsiveness and empathy variables each show no significant influence on customer satisfaction. This research found that the guarantee variable has the greatest influence on customer satisfaction.

Keywords: physical evidence (tangibles), reliability, responsiveness, assurance, and empathy, customer satisfaction.
\end{abstract}

\section{ABSTRAK}

Tujuan penelitian ini untuk mengetahui pengaruh kualitas pelayanan terhadap kepuasan pelanggan pada kantor Kesyahbandaran dan Otoritas Pelabuhan Kelas II Pontianak. Populasi yang digunakan dalam penelitian ini sebanyak 81 oran (sensus). Penelitian ini menggunakan analisis Regresi Linier berganda, dengan sofware statistik SPSS. Variabel kualitas pelayanan, dengan dimensi bukti fisik dan jaminan masing-masingmasing mempunyai pengaruh yang positif dan signifikan terhadap kepuasan pelanggan, kemudian variabel kehandalan, daya tanggap dan empati masing-masing tidak memiliki pengaruh yang signifikan terhadap kepuasan pelanggan. Riset ini menemukan bahwa variabel jaminan memiliki pengaruh yang paling besar terhadap kepuasan pelanggan.

Kata kunci: bukti fisik, keandalan, daya tanggap, jaminan, dan empati, kepuasan pelanggan. 


\section{INTRODUCTION}

The strategic place of the Indonesian State makes Indonesia an important role in world trade. Even since the $7^{\text {th }}$ century, Indonesia has become an important trading area by establishing religious and trade relations with China and India. As an archipelagic country that has an important role in trade, Indonesia optimizes sea transportation as a medium of liaison with other countries.

The period of free trade is increasingly becoming an economic concept adopted by many countries in the world, including Indonesia. Free trade can be defined as the sale of products between countries without export-import taxes or other trade barriers. With the implementation of free trade in Indonesia, the flow of goods from or to Indonesia will increase sharply.

Therefore, an efficient and effective means of transportation is very important to create transportation operating costs at a minimum level. One of the very inexpensive means of transportation to support export and import activities is transportation by sea. Thus a port is needed as a place of connection between sea and land modes. The port as a provider of port services is expected to be able to provide excellent service so that exporters and importers are not disadvantaged by increasing costs due to sub-optimal service.

The ports that have the management must be based on the principles of the corporate economy and with high professionalism. Apart from functioning as public utilities or carrying out missions in the public interest, the government has also assigned the task of making public ports to obtain adequate profits, to maintain the continuity of port services in Indonesia.

Pontianak Class II Port Authority is one of the offices that have the task of carrying out supervision and law enforcement in the field of shipping safety and security, coordinating government activities at ports as well as regulating, controlling, and supervising port activities at commercially operated ports.Pontianak Class II Port Authority and Port Authority have animportantactivityfor ship at the port. The types and procedures of hospitality services greatly tomeasure the gradeofpleasureof service users with the providertreatment. The types of services that are provided in the harbormaster service are fishing logbooks, evidence of ship arrival reports, sailing approval letters, the extension of SIKPI / SIPI vessels measuring 30 GT to $60 \mathrm{GT}$, recommendations for subsidized fuel, and certification of fish catches.

To achieve the success of this work, the Class II Pontianak Port Authority and Harbormaster Office can strive to improve the ability of employees, especially in terms of performance. Employee performance is certainly very much influenced by the internal conditions of each employee as well as the external conditions that surround them which in turn will determine the level of satisfaction of users of hospitality services.To find out the extent to which the Class II Port Authority and Port Authority's ability to provide satisfaction through their services, research is needed. The information from the research results aims to determine the attitudes and behavior of customers towards what is most influential in deciding to become a Class II Port Authority and Port Authority customer of Pontianak.Given the strategic role of customer satisfaction in the existence of the Pontianak Class II Port Authority and Port Authority, the authors 
are interested in exploring the factors that affect customer satisfaction, especially from its services.The following is data on existing customer complaints, namely regarding errors in ship service invoices from 2015 to 2017.

Table 1.

Customer Complaint Data and Follow Up 2015-2017

\begin{tabular}{cccc}
\hline Year & Number & Follow-Up & Information \\
\hline 2015 & 39 & Done & $100 \%$ \\
2016 & 45 & Done & $100 \%$ \\
2017 & 36 & Done & $100 \%$ \\
\hline \multicolumn{5}{l}{ Source: Port Authority and Harbormaster Office Class II Pontianak }
\end{tabular}

From Table 1. above, it is explained that there is an enhancement in the total of customer complaints from everyyear regarding invoicing errors. Where 2016 had the highest number of complaints than in 2015 and 2017.Based on the problem formulation above, the aim of the research to be achieved is to measure the impact of service quality which consists of tangibles, reliability, responsiveness, assurance, and empathy on customer satisfaction. Pontianak Class II Port Authority.

Quality incorporates many definitions and meanings due to the fact extraordinary humans will interpret it differently, together with compliance with necessities or demands, suitability for non-stop restore use, unfastened from harm or defects, assembly client needs, doing everything happy (Tjiptono, 2006). Meanwhile, according to Karsono (2007), service quality is a consumer's evaluation of typical provider reliability and superiority. Consumers will make comparisons among what they offer and what they get. According to Kotler and Keller (2008) "Quality is the best guarantee for customer loyalty the strongest defense in the face of competition, and the only path to sustainable growth and income".

Tjiptono (2008) define "Service Quality as a degree of ways nicely the extent of provider supplied can in shape consumer expectations. Based in this definition, carrier best is decided via way of means of the company's cappotential to fulfill purchaser want and desires the subsequent purchaser expectations.In different words, the primary elements that impact provider excellent are the anticipated provider and perceived provider (Parasuraman et al., 1988). In providing good service to customers, there are five determining criteria for service quality as expressed by Parasuraman et al. (1988), in their research found and managed to identify five main dimensions of service quality cited by Tjiptono (2008), namely : (first) Tangibles (physical evidence) Concerning the bodily look of provider facilities, equipment, human resources, and corporation verbal exchange materials. (second) Reliability, Relates to the company's cappotential to supply offerings which are provided accurately. (third) Assurance (Guarantee), Regarding the know-how and politeness of personnel and their capacity to foster client believe and confidence. (fourth) Empathy means that the enterprise is familiar with the issues of its clients and acts withinside the hobbies of clients, in addition to giving non-public interest to clients and having snug running hours. 
(fifth) Responsiveness, Regarding the willingness and cappotential of provider companies to assist clients and reply to their requests immediately.

The author tries to review the latest research related to service quality on customer satisfaction.

Research conducted by Afthanorhan et al. (2019), About constant concern of academic institutions has been to improve the customer satisfaction in university libraries. The service quality within academic library context is pivotal for satisfying customers by meeting the customers' needs to create loyalty amongst customers. This research usesLibQual to analyze the gap between customer's perception and expectation, concerned with theservices at the University Sultan Zainal Abidin (UniSZA) Library. There are six dimensions inservice quality; namely general services, search for materials, library collection, staff, environmentand environment, considered for this empirical research. The purpose of this paper is to 1) knowservice quality dimensions that satisfy the customers and 2) to observe the impact of service qualityon customer satisfaction. The research methodology is carried out using a questionnaire surveydistributed among 170 samples through simple random sampling. The data obtained was analyzedby using covariance-based structural equation modeling and importanceperformance analysis. Theresults suggest that quality of service had a significant impact on customer satisfaction. Among theservice quality dimensions, library environment and general service were viewed as high importance and strong performance index. Implication for research and practice resulting from thesefindings were also discussed.

Research conducted by Alam and Noor (2020), Facing giant competition, stores throughout the globe are experiencing discount of their purchaser loyalty. This lowering fashion is even extra observable withinside the superstore retailing in Bangladesh; specially whose goal marketplace is younger cohort (Generation Y). As a result, it's far critical for the superstore proprietors to examine the elements affecting the purchaser loyalty of Gen Y. The primary motive of this observe is to analyze the impact of provider best and company photo on purchaser loyalty of Gen Y withinside the retail superstores of Bangladesh. A overall of 325 Gen Y buyers had been surveyed from 4 main superstores in Bangladesh the use of a dependent questionnaire. Smart-PLS 3.zero software program changed into used to validate the amassed statistics and take a look at the statistical importance of the course relationships through following structural equation modeling. The outcomes suggest that Gen Y customers' loyalty in the direction of the superstores is definitely and considerably prompted through each provider best and company photo. The outputs additionally screen that provider best not directly influences Gen Y purchaser loyalty in the direction of superstores with an intervening position of company photo. Research implications from theoretical and realistic standpoints in addition to the suggestions for imminent observe also are provided.

According to research by Bhatt (2020), still a few research have investigated banking offerings from equity angle and not one of the research have tried to degree provider equity in Indian retail banking offerings context, the paper seeks to analyze provider equity in Indian retail banking offerings context. It tries to validate the prevailing 4-dimensional provider equity scale and investigates its 
applicability withinside the retail banking industry. The conceptual version depicting the connection among provider equity, provider fine and consumer pleasure changed into examined the use of SEM. The effects installed reliability and validity of the size and the effect of provider equity on provider fine and consumer pleasure. The effect of man or woman equity dimensions on those consumer assessment variables is likewise studied. The paper discusses crucial implications of the findings and gives precious insights for the practitioners in addition to academia.

Followed by research conducted by Fida et al. (2020), who tries to observe the effect of carrier first-rate on patron loyalty and patron pride the usage of the SERVQUAL version for 4 foremost Islamic banks with inside the Sultanate of Oman. This is a quantitative nature of a have a look at, which worried a structured, self-administered questionnaire primarily based totally on a comfort sampling techniqueaccumulatingfacts from a hundred and twentyclients of Islamic banks in Oman. The have a look atfactshad been analyzed the usage of SPSS, and the reliability coefficient (Cronbach's alpha) changed into established. The correlation evaluationtested the vast relationships a number of thehave a look at variables. The effect of carrierfirst-rate dimensions on patronpridechanged into captured via regression evaluation. The key findings of the have a look atdiscovered that the respondents confirmed on common an "Agree" reaction with inside the 5 areas, namely, tangibles, responsiveness, reliability, assurance, and empathy. The correlation effects depicted a vast dating among the 3 variables: carrierfirst-rate, patron pride, and patron loyalty. Similarly, regression effects proven that empathy and responsiveness dimensions have a vast advantageous effect on patron pride. It is, therefore, advocated that banks have to awareness extra on empathy and responsiveness thinking about the vastdatingof those variables on patron pride. However, banks have tonow no longeroverlook the significance of different variables consisting of reliability, assurance, and tangibles which can be discovered as crucialvia way of means of responses of the individuals for the bank's provisions.

There are many definitions of customer satisfaction that have developed from satisfaction experts, as quoted by Tjiptono (2008), including: (i) Feelings that arise after evaluating the experience of using the product. (ii) Customer responses to perceptual critiques of the distinction among preliminary expectancies earlier than purchase (or different overall performance standards) and the actual universal overall performance of the product as perceived after the usage of or ingesting the product. (iii) An typical after-buy assessment evaluating perceptions of product overall performance with pre-buy expectations. (iii) A degree of an organization's general product overall performance as opposed to a fixed of purchaser requirements (iv) The degree of a person's feelings after comparing the performance (or results) he perceives in comparison to his expectations. (v) customer satisfaction is the degree of a person's emotions after evaluating the performance (results) he feels in comparison to his expectations. Furthermore, in meeting customer satisfaction, argues that agencies ought to make extra efforts to growth customer expectancies and be balanced with what's produced. Companies have to additionally be capable of make customers sense 
very satisfied, due to the fact customers who most effective say they're pretty satisfied, it's far nonetheless clean to alternate to different merchandise in the event that they get a higher offer.

Followed by research conducted by Khatoon et al. (2020), this research investigates the connection among the size of electronic (E)-banking provider best and patron buying intentions with the mediating function of patron pleasure. Data had been amassed from personnel and clients, running in distinct banks of Qatar thru a established closed-ended questionnaire from a pattern of 235. Correlation evaluation and regression evaluation had been implied to the acquired statistics to check the look at hypothesis, and the document supplied correct outcomes as in line with our expectations. The outcomes of the look at suggest that reliability, efficiency, responsiveness, communication, security, and privateness have a sizeable and fine effect on patron buying intentions. Customer buying intentions are notably accelerated while the clients are happy with E-banking provider best. The mediating function of patron pleasure turned into hooked up for E-banking provider best and patron buy intentions. Customer pleasure examined as a mediator has proven a partial effect on the connection among statistics technology (IT), E-banking provider best, and patron buying intentions. This look at has notably contributed to the region of studies frequently in the area of behavioral finance. The look at additionally affords sizeable implications for academicians and practitioners.

Further research developments were carried out by Prentice et al. (2020), this research attempted to discusses synthetic intelligence (AI) - powered programs as a industrial carrier with a focal point at the resort industry. This studies is approached fromthe customers' angle and examines how AI and worker carrier best have an effect on consumer pleasure and loyalty. The examine changed into carried out in more than one lodges in Portugal and centered on departure visitors who had skilled each AI and worker offerings related to the surveyed lodges. The outcomes display that each AI and worker carrier best give an explanation for sizeable variances in typical carrier best evaluation in addition to consumer pleasure and loyalty. However, handiest positive carrier best dimensions made specific var- iances withinside the results of interest. When regressing each AI and worker carrier best withinside the identical equation, AI will become terrible and insignificant. This examine contributes to the AI and consumer loyalty studies. The findings of this examine have monetary implications for lodges and offer insights into most reliable aid allocation.

Further studies tendencies have been finished by Ekaabi et al. (2020), this paper is to research the multidimensional con- structs of clever policing carrier high-satisfactory, and the effect of those size at the pride tiers of UAE residents. An on-line survey turned into performed the use of a pattern of 230 respondents and analyzed the use of structural equation modeling. The findings of this take a look at verify that integrity and serviceability have a full-size and nice effect on pride. When hedonic dimensions are controlled, it turned into located that integrity, transparency, responsivity, interactivity, and serviceability are full-size predictors of pride. When utilitarian dimensions are controlled, simplest integrity, transparency, interactivity and serviceability are full-size associated with pride. 
This take a look at contributes to the policing and carrier high-satisfactory studies due to the fact confined research show how clever policing carrier highsatisfactory dimensions power satisfac- tion. This studies extends past present day e-carrier high-satisfactory fashions via way of means of addressing the significance of utilitarian size in police offerings high-satisfactory. Such elements and their strategic relation to pride are regularly neglected withinside the public area for the sake of retaining long time relationships with residents; a area wherein customers are believed to be frequently pushed via way of means of hedonic motives.

Subsequent developments were written by De Leon et al. (2020), This research talks about the bank, which provide technology-primarily based totally self-carrier banking inclusive of cell bank- ing programs to maintain up with technological advancement. The utilization of this software calls for pleasant carrier delivery. However, there's a dearth of literature on post-adoption and carrier pleasant evaluation of cell banking programs. Therefore, the principle goal of this observe is to evaluate if the Self-Service Technology carrier pleasant (SSTQUAL) dimensions have an effect on the perceived cost and purchaser delight in cell banking programs. The statistics changed into accrued from 2 hundred customers of cell banking. Data evaluation changed into executed with Structural Equation Modelling (SEM) the use of AMOS. Service pleasant is a second-order element composed of 7 first- order elements of pleasant dimensions. The findings of this observe display that carrier pleasant notably impacts the perceived cost and purchaser delight. These findings offer insights for banks and cell software companies to increase techniques so that it will decorate purchaser experience, perceived cost, and purchaser delight.

Further developed by Tuncer et al. (2020), where the goal of this observe is to decide the outcomes of provider fine, perceived cost and patron delight on behavioral intention. The observe additionally introduces a brand new incorporated structural version that mixes provider fine's dimensions of meals qual- ity, worker provider fine, timeliness, esthetics, facility com- castle and cleanliness. An explanatory and a confirmatory issue evaluation turned into carried out to expand and affirm the six-dimensional provider fine scale primarily based totally on facts received from 309 custo- mers who obtained provider from a specific restaurant. Path evaluation turned into additionally carried out to study the relationships of provider fine, perceived cost, and patron delight with behavioral intention. The effects display that provider fine has a fine impact on patron delight, at the same time as patron satis- faction and perceived cost have fine outcomes on customers' behavioral intentions. In addition, different dimensions aside from aesthetics have a fine function in patron delight, at the same time as provider fine, facility consolation and timeliness have a fine impact on perceived cost. This observe contributes to the provider fine literature and has sensible managerial implications.

Further developments submitted by Chikazhe et al. (2020), this study focuses on impact on graduates' perceived carrier fine, graduates' delight and loyalty on graduates' perceived process overall performance are scarce. Therefore, this look at changed into performed to slim this expertise gap. A cross- 
sectional survey of 430 college graduates changed into completed in Harare, Zimbabwe. Structural equation modelling changed into used to check the studies hypotheses. Results display that graduates' perceived carrier fine and loyalty every definitely impacts graduates' perceived process overall performance. It changed into discovered that graduates' delight does now no longer considerably impact graduates' perceived process overall performance.

Further research developments are explained by Caruana et al. (2020), who performs the instrument diagnostic observation and exploratory studies which undertaken amongst clients of an audit organization to decide whether or not cost performs a moderating function among provider best and delight. Results from a moderated regression confirming this kind of function for cost are reported. Implications are drawn and possibilities for in addition studies are highlighted.

Subsequent research development carried out by Nunkoo et al. (2020), this studies contributes to patron pleasure know-how in regards to lodging in South Africa whose famous person grading differs. A multi-organization evaluation and an importance-overall performance map evaluation via PLS-SEM permit us to distinguish among carrier excellent overall performance rankings and their impacts on patron pleasure throughout lodging with a one of a kind famous person grading. The maximum crucial predictors of pleasure with one-famous person and -famous person class lodging are the lodging infrastructure and the worker expertise. Both predictors had been determined to have rather low degrees of overall performance. Safety and protection and room excellent are huge determinants of pleasure with three-famous person establishments, despite the fact that they under-carry out in regards to protection and protection. In recognize of four-famous person and five-famous person lodging, ready time and patron interaction, each of that have above common overall performance rankings, have an effect on patron pleasure. We offer unique suggestions for managerial interventions to enhance carrier excellent and guests' pleasure for every grading class

Research with case studies in Vietnam was carried out by Le et al. (2020), this paper objectives to validate 5 determinants of carrier high-satisfactory and to take a look at the carrier qualitycustomer delight hyperlink withinside the port logistics carrier enterprise of a growing and transitional economy. First, the studies evaluations literature pertinentto carrier high-satisfactory and consumer delight. Second, it makes use of each qualitative and quantitative techniques thru consciousness institution dialogue and directinterviews with 212 respondents who're the personnel of companies which have been the usage of port logistics carrier furnished via way of means of Cat Lai Port, Ho Chi Minh City, Vietnam. Finally, the multivariate evaluation is ultimately hired to research statistics acquired from surveys via way of means of structural equation modeling (SEM) technique. Findings imply that port logistics carrier high-satisfactory is definitely decided via way of means of 5 elements together with responsiveness, assurance, reliability, tangibles and empathy. In addition, port logistics carrier highsatisfactory exerts fine impact on consumer delight. Most noticeably, as embedded withinside the tangibles component, technological improvements seem 
to beautify carrier high-satisfactory which in the end satisfies clients withinside the port logistics carrier enterprise.

Research development continued by Özkul et al. (2020), this studies objectives to decide whether or not the colour of mild withinside the carrier ecosystem influences the purchaser's best perceptions and purchaser pride and whether or not this impact differs in line with the colour of mild. To this end, the eating place business, which has an vital area withinside the tourismindustry, turned into selected because the studies test ambient. A overall of 5 experiments have been performed in 5 ambient lighted in one-of-a-kind colours with participants. Data have been gathered with 204 the shape of the test query According to the evaluation results, the notion of carrier best and the extent of pride have been better in purple and yellow-lighted ambient than the ones in blue and greenlighted ambient. In line with the results, pointers have been made to lessen the bodily surroundings charges withinside the carrier manufacturing technique in eating places and to acquire a purifier carrier manufacturing, sustainable manufacturing, and intake via greater green use of resources.

According to Sugiyono (2007), a variable is an characteristic or nature or cost of a person, object, or hobby that has positive versions decided via way of means of the researcher to observe and draw conclusions. The research variables consisted of two kinds, namely the dependent variable or variables that were dependent on other variables, and the independent variable or variables that did not depend on other variables.

In this study, the structured variable is consumer satisfaction (Y). The structured variable is the variable this is the principle cognizance of the researcher. The essence of a trouble is without problems visible with the aid of using spotting the diverse structured variables utilized in a model. The variability of those elements is researcher attempts to explain (Ferdinand, 2006).

The independent variable which is denoted by $(\mathrm{X})$ is a variable that affects the dependent variable, whether the influence is positive or the one has a negative effect (Ferdinand, 2006). The independent variables in this study are: Tangible (X1), Reliability (X2), Responsiveness (X3), Assurance (X4), Empathy (X5)

The physical aspect according to Tjiptono (2006) is trying to improve service facilities, such as large and safe parking lots, the number of cashiers so that the queue is not too long. Physical centers encompass bodily centers, equipment, employees, and method of conversation following customer expectations. Referring to the theory above, the indicators for Tangible are: (i) Condition of the service room, (ii) Visitor queuing sistem, (iii) Availability of uniforms and official identification, (iv) Hours of service, (v) Service fee.

Reliability is the capacity to offer the promised carrier immediately, accurately, and satisfactorily (Tjiptono, 2006). Referring to the theory above, the indicator of reliability is: (i) Availability of several officers, (ii) Clear service procedure, (iii) Officers provide the same service to everyone (iv) The ability of officers to provide services, (v) Quality of services provided.

Responsiveness according to Pena et al. (2013); Naik et al. (2010) is the provision of appropriate and responsive services. The degree of willingness or challenge could be visible to what quantity the employer attempts to assist its 
consumers. The shape may be carried out with the aid of using handing over clean information, movements which could gain customers. Referring to the theory above, the indicators for Responsiveness are: (i) The speed of the officers in resolving complaints, (ii) The speed of the officer in responding to user wishes, (iii) Speed of service process, (iv) suitability of service, (v) Officers are on the spot when needed.

Assurance according to Parasuraman et al. (1988) is the knowledge, politeness, and cappotential of business enterprise personnel to foster customers' consider withinside the business enterprise. this consists of numerous additives together with communication, credibility, security, competence, and courtesy. Referring to the theory above, the indicators for Assurance are: (i) Customers' sense of security from document loss, (ii) The certainty of service costs, (iii) Knowledge of officers related to services provided, (iv) Availability of proof of transaction, (v) Guarantee to maintain the confidentiality of documents.

Empathy is the convenience of creating relationships, precise communication, non-public attention, and know-how purchaser needs (Tjiptono, 2006). Referring to the theory above, the indicators for empathy are: (i) Officers provide the information needed by users, (ii) Friendliness and courtesy of officers, Ease of payment, (iii) There is a channel/media for submitting user complaints, (iv) The conformity between the services provided and the existing procedures

According to Tjiptono (2006), client pride is an after-buy assessment in which the selected opportunity offers at the least the equal effects or exceeds expectations, whilst dissatisfaction arises if the effects received do now no longer meet expectations. Referring to the theory above, the indicators for customer satisfaction are: (i) Customers are satisfied with the various facilities provided, (ii) Customers are satisfied with the responsiveness of Class II Port Authority and Port Authority officers of Pontianak, (iii) Customers are glad with the rate of carrier provided by the Port Authority and Class II Pontianak Port Authority, (iv) Customers feel confident that employees of the Class II Port Authority and Port Authority of Pontianak can serve consumers fairly, (v) Customers feel confident that the employees of the Class II Port Authority and Port Authority of Pontianak can solve the problems they are facing.

Research results by Gopi and Samat (2020), shows that service first-class may be characterised because the discrepancy among customer support requirements and real provider. When expectancies are better than performance, perceived first-class is much less than proper and consequently patron unhappiness exists which finally decreases patron loyalty in the direction of a product or provider. Customer delight is one of the important dreams of any company. Organizations recognize that it's miles extra worthwhile to maintain modern clients than to win new ones to update the ones lost. Therefore, it's miles essential for all of the meals truck providers to recognize the significance of provider first-class that glad patron wishes which have an effect on the loyalty of the patron. Thus, this studies has discovered the have an effect on of meals vehicles provider first-class on patron delight and its effect in the direction of patron loyalty. The SERVQUAL version turned into used to degree patron delight 
which has 5 dimensions: tangibles, reliability, responsiveness, warranty and empathy.

\section{RESEARCH METHODS}

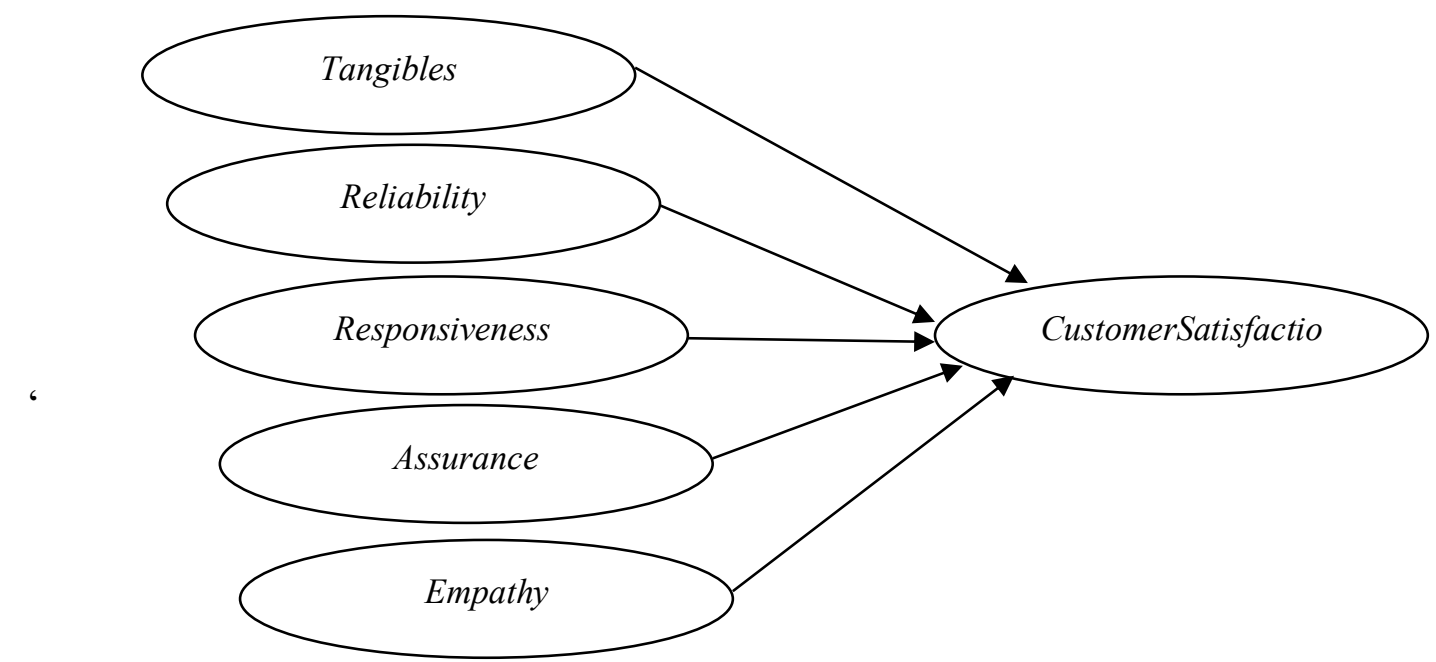

\section{Image 1. Research Model}

This form of studies on this examine makes use of descriptive correlational which reveals the extent to which the tangible variables, reliability, responsiveness, assurance, and empathy are related as independent variables (X) and customer satisfaction as the dependent variable (Y). Correlational research is "research designed to determine the level of relationship between different variables in a population".

In this study, it will be known how much the contribution of the independent variables to the dependent variable and how much the relationship occurs using a quantitative approach. This research consists of six variables which include independent variables: Tangible (X1), reliability (X2), responsiveness (X3), assurance (X4), empathy (X5), and the dependent variable namely customer satisfaction (Y). To test the hypothesis, multiple regression analysis is used, in which the technique will test the hypothesis which states that there is an influence between the independent variable and the dependent variable. According to Arikunto (2006) multiple regression analysis is an analysis of the relationship between one dependent variable with or more independent variables.

In this study, the population is all customers of the Class II Port Authority and Port Authority of Pontianak. A populace is a set of people, events, or the entirety that has positive characteristics. The population in this study were all 81 customers or customers of the Port Authority and Port Authority of Class II Pontianak consisting of representatives of shipping agents. Because the entire population will be researched, a census of the entire population of 81 shipping agents will be carried out. Sugiyono (2004), the pattern is a part of the range and traits possessed through the population. 
The sample taken in this study amounted to 81 respondents. Sampling in this study using the Census method where all populations are sampled. Obtained through a list of questions/statements submitted to respondents in this study. Data obtained from reports and databases that exist at the Port Authority and Class II Pontianak Port Authority.

Data collection techniques in this research are through, (1) Observation, conducting direct observations of the object under study, so that the data collected is more objective, (2) Interview, by holding questions and answers to the respondents of the Pontianak Class II Port Authority and Port Authority to obtain the required information, (3) Documentary study, from reports or documents relating to the object being examined.

\section{RESULT AND DISCUSSION}

Table 2.

Respondent Characteristics

\begin{tabular}{lll}
\hline Gender & Total (Person) & Percentage (\%) \\
Man & 73 & 90.12 \\
Woman & 8 & 9.88 \\
Total & 81 & 100.00 \\
\hline Age (years) & Total (Person) & Percentage (\%) \\
\hline $20-25$ & 4 & 4.94 \\
$26-30$ & 11 & 13.58 \\
$31-35$ & 50 & 61.73 \\
$35>$ & 16 & 19.75 \\
Total & 81 & 100.00 \\
\hline Education & Total (Person) & Percentage (\%) \\
SMA & 20 & 24.69 \\
Diploma & 40 & 49.38 \\
S-1 & 16 & 19.75 \\
S-2 & 5 & 6.17 \\
Total & 81 & 100.00 \\
\hline Source: processed & data in 2019 &
\end{tabular}

Source: processed data in 2019

Table 3.

Validity test

\begin{tabular}{|c|c|c|c|}
\hline Variable & Indicator & $\mathbf{r}_{\mathbf{g}}$ & r_tabel \\
\hline \multirow[t]{2}{*}{ Tangibles } & Service room conditions & 0,606 & 0,182 \\
\hline & Visitor queue system & 0,614 & 0,182 \\
\hline
\end{tabular}

Continued... 
Continued Table 13.

\begin{tabular}{|c|c|c|c|}
\hline Variable & Indicator & $\begin{array}{r}r_{\text {_hitun }} \\
\mathrm{g}\end{array}$ & r_tabel \\
\hline \multirow{7}{*}{ Reliability } & Availability of uniforms and official identification & 0,777 & 0,182 \\
\hline & Service hours & 0,615 & 0,182 \\
\hline & Service fee & 0,729 & 0,182 \\
\hline & Availabilityofnumberofofficers & 0,603 & 0,182 \\
\hline & Thereis a clearserviceprocedure & 0,618 & 0,182 \\
\hline & Officersprovidethesameservicetoeveryone & 0,662 & 0,182 \\
\hline & The abilityofofficers in providingservices & 0,772 & 0,182 \\
\hline \multirow{3}{*}{ Responsiveness } & Qualityofserviceprovided & 0,752 & 0,182 \\
\hline & Officerspeed in resolvingcomplaints & 0,777 & 0,182 \\
\hline & The speedofthestaff in respondingtouserwishes & 0,663 & 0,182 \\
\hline \multirow{7}{*}{ Assurance } & Service processspeed & 0,629 & 0,182 \\
\hline & Service as desired & 0,623 & 0,182 \\
\hline & Officers are onthespotwhenneeded & 0,702 & 0,182 \\
\hline & Customersenseofsecurityfromdocumentloss & 0,610 & 0,182 \\
\hline & Certaintyofservicefees & 0,761 & 0,182 \\
\hline & Officerknowledgeregardingtheservicesprovided & 0,605 & 0,182 \\
\hline & Availabilityofproofoftransaction & 0,607 & 0,182 \\
\hline \multirow{3}{*}{ Empathy } & Guaranteetomaintaintheconfidentialityofdocuments & 0,766 & 0,182 \\
\hline & The clerkprovidestheinformationneededbytheuser & 0,651 & 0,182 \\
\hline & Friendlinessandcourtesyofofficers & 0,622 & 0,182 \\
\hline \multirow{7}{*}{$\begin{array}{l}\text { Customer } \\
\text { Satisfaction }\end{array}$} & Easeofpayment & 0,605 & 0,182 \\
\hline & $\begin{array}{l}\text { Thereis a channel / media forsubmittingusercomplaints } \\
\text { The } \\
\text { suitabilityoftheservicesprovidedwithexistingprocedures }\end{array}$ & 0,720 & 0,182 \\
\hline & Facilitiesprovided & 0,608 & 0,182 \\
\hline & Officerresponsiveness & 0,796 & 0,182 \\
\hline & Speedofserviceprovided & 0,609 & 0,182 \\
\hline & serveconsumersfairly & 0,683 & 0,182 \\
\hline & abletoovercometheproblemsitfaces & 0,662 & 0,182 \\
\hline
\end{tabular}

Source: processed data in 2019

Table 3. indicates that every one the signs used to degree the variables used on this observe have a correlation price more than 0.182 . These effects imply that every one of those signs are valid.

Table 4 . The effects of the reliability take a look at suggest that every one variables have an Alpha coefficient of extra than 0.6, so it is able to be stated that every one the measuring ideas of every variable of the questionnaire are dependable, because of this that that the questionnaire used on this have a look at is a dependable one. 
Table 4.

\begin{tabular}{ll}
\multicolumn{2}{c}{ Reliability Test } \\
\hline Variable & $\boldsymbol{\alpha}$ \\
\hline tangibles & 0,689 \\
reliability & 0,709 \\
responsiveness & 0,685 \\
assurance & 0,678 \\
empathy & 0,642 \\
Customer satisfaction & 0,691 \\
\hline Source: processed data in 2019
\end{tabular}

The multicollinearity check targets to decide whether or not withinside the regression version there may be a correlation among impartial variables. Multicollinearity approach that there may be an ideal dating among a few or all the variables that designate the regression version. The foundation for seeing a version that isn't suffering from multicollinearity is to examine the Variance Inflation Factor (VIF) and the tolerance level. If VIF $>5$ and Tolerance $<0.1$, then multicollinearity is affected, but if VIF $<5$ and Tolerance $>0.1$, then there is no multicollinearity problem in this study. The test results can be seen as follows:

Table5.MulticollinearityTestResults

\begin{tabular}{lll}
\hline Variable & Tolerance & VIF \\
\hline Tangible (X1) & 0,566 & 1,766 \\
Reliability (X2) & 0,665 & 1,503 \\
Responsiveness (X3) & 0,607 & 1,648 \\
Assurance (X4) & 0,674 & 1,484 \\
Empathy (X5) & 0,778 & 1,285 \\
\hline Source. Process Data 2019 & &
\end{tabular}

Source: Process Data 2019

From the table above, it can be concluded that the regression model is feasible to use in this study because the requirements for multicollinearity have been met, namely a tolerance value $>0.10$ with a VIF value $<10$.

To decide the presence or absence of heteroscedasticity signs and symptoms may be accomplished with the aid of using the use of a heteroscedasticity graph one among the anticipated cost of the based variable and the impartial variable. From the scatterplots, it is able to be visible that the dots are unfold randomly and are unfold both above or underneath the wide variety zero and $\mathrm{Y}$ axis, it is able to be concluded that there's no heteroscedasticity withinside the regression version, so the regression version is possible to apply in testing. For extra details, it is able to be visible in one of the following graphics, at the left side.

A normality check changed into accomplished the use of the P-P Plot graph. Data is stated to be regular while the statistics paperwork factors that unfold now no longer some distance from the diagonal line. The outcomes of linear regression evaluation with the regular graph P-P Plot at the residual mistakess of the regression version display that there's a regular picture pattern, specifically the distribution of factors now no longer some distance from the diagonal line. The 
check outcomes on graph one, withinside the photo to the right, display that the dots are across the diagonal line. This manner that the regression version is commonly distributed.
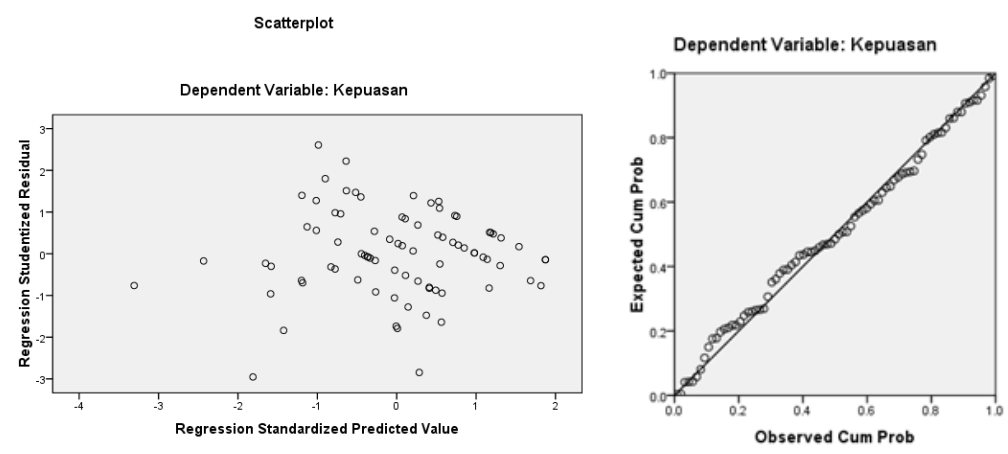

\section{Graphics 1. Heteroscedasticity and Normality Test.}

The coefficient of determination $\left(\mathrm{R}^{2}\right)$ is used to determine the ability of the model to explain the dependent variable. The results of the coefficient of determination $\left(\mathrm{R}^{2}\right)$ can be seen in Table 6 . below:

Table 6.

Coefficient of Determination

\begin{tabular}{ccccc}
\hline Model & R & R Square & $\begin{array}{c}\text { Adjusted R } \\
\text { Square }\end{array}$ & $\begin{array}{c}\text { Std. Error of } \\
\text { the } \\
\text { Estimate }\end{array}$ \\
\hline 1 & $.685^{\text {a }}$ & .469 & .433 & 1.52253 \\
\hline Source: processed data in 2019 & &
\end{tabular}

R Square of 0.685 means $68.5 \%$ of the Customer Satisfaction variable can be explained by the Tangible variables (Physical Evidence), Reliability, Responsiveness, Assurance, and Empathy. While the other $31.5 \%$ are influenced or explained by other variables not discussed in this study.

The $\mathrm{F}$ test is carried out to see whether the independent variables consisting of Tangible, Reliability, Responsiveness, Assurance, and Empathy which are included in the model have a joint influence on the dependent variable. namely Customer Satisfaction.

This simultaneous test is to compare the calculated $\mathrm{F}$ value with the $\mathrm{F}$ table value at a significant level of 0.05 . The $F$ table value of 0.05 is obtained by considering the value of the degree of freedom (df) or $(\mathrm{k}-1)$ and $(\mathrm{n}-\mathrm{k})$, where $\mathrm{k}$ is the number of variables and $n$ is the number of samples. The results of the $F$ Test Multiple Regression analysis are shown through the Analysis of Variance in Table 7. below: 
Table 7.

F Test

\begin{tabular}{llrrrrr}
\hline Model & & Sum of Squares & df & Mean Square & F & \multicolumn{1}{l}{ Sig. } \\
\hline 1 & Regression & 153.278 & 5 & 30.656 & 13,224 & $.000^{\mathrm{a}}$ \\
& Residual & 173.858 & 75 & 2.318 & & \\
& Total & 327,136 & 80 & & & \\
\hline
\end{tabular}

Source: processed data in 2019

From the results of the analysis in the table above, it is known that simultaneously the calculated $\mathrm{F}$ value is 13.224 at a significant level of $0.000 \mathrm{a}$ and because the probability level of $0.000 \mathrm{a}$ is much smaller than 0.05 , this regression model can be used to predict the factors that affect Customer Satisfaction in the and Pontianak Class II Port Authority.

Based on the F distribution table (Supranto, 2001) it can be seen that the F table value of 0.05 in (5) (75) is 2.34. The results of the regression analysis show that the calculated $F$ value is 13.224. So when compared, the calculated F value $>$ F table value, then $13.224>2.34$, so it can be concluded that Customer Satisfaction at Port Authority and Port Class II Pontianak is significantly influenced by Tangible (Physical Evidence), Reliability, Responsiveness variables, Assurance, and Empathy.

To find out the effect of the Tangible (X1), Reliability (X2), Responsiveness (X3), Assurance (X4), and Empathy (X5) factors on Customer Satisfaction at PT. The Port of Pontianak Class II Port Authority and Port Authority carried out a Partial Test (t-test). The analysis results can be seen in Table 8 .

\section{Table 8 . \\ t-Test}

\begin{tabular}{lllllr}
\hline \multicolumn{7}{c}{ Unstandardized Coefficients Standardized Coefficients } \\
Model & B & Std. Error & Beta & t & Sig. \\
\hline 1 (Constant) & 3.947 & 2.546 & & 1.550 .125 \\
Tangible & .268 & .105 & .285 & 2.551 .013 \\
Reability & .193 & .100 & .200 & 1.934 .057 \\
Responsiveness & -.009 & .105 & -.009 & -.083 .934 \\
Assurance & .321 & .099 & .332 & 3.242 .002 \\
Empathy & .077 & .101 & .073 & $.763 \quad .448$ \\
\hline
\end{tabular}

Dependent Variable: Kepuasan

Source: processed data in 2019

The partial analysis was performed by comparing the $t$ value of the $t$ table at $\alpha 0.05$. The value of the $t$ table can be found by determining the degree of freedom, namely (n - k) at $\alpha 0.05$, then $(81-6) \alpha 0.05=1.665$ (Supranto, 2001).

Partially the Physical Evidence variable has a $t$ value of 2.551 which is greater than t table $\alpha 0.05$, then 2.551>1.665. So it can be concluded that this research variable Physical Evidence partially has a significant effect on customer satisfaction at PT. Port of Pontianak Class II Port Authority and Authority. These 
two variables are contrary to research conducted by Fida et al. (2020), but in accordance with the research conducted by Gopi and Samat (2020).

Partially the reliability variable has a t value of 1.934 which is greater than $t$ table $\alpha 0.05$, then $1.934>1.665$. So it can be concluded that this research variable reliability partially has no significant effect on customer satisfaction at PT. Port of Pontianak Class II Port Authority and Authority. The relationship between reliability and customer satisfaction is in accordance with the research conducted by Fida et al. (2020) but the results differ from the research conducted by Gopi and Samat (2020).

The partial responsiveness variable has a $t$ value of -0.009 which is smaller than $\mathrm{t}$ table $\alpha 0.05$, then $-0.009<1.665$. So it can be concluded that this research variable responsiveness partially has no significant effect on customer satisfaction at PT. Port of Pontianak Class II Port Authority and Authority. These two variables are contrary to research conducted by Fida et al. (2020). But the results are in accordance with the research conducted by Gopi and Samat (2020).

Partially the guarantee variable has a t-count value of 3.242 which is greater than $t$ table $\alpha 0.05$, then $3.242>1.665$. So it can be concluded that this research variable partially guarantees a significant effect on customer satisfaction at PT. Port of Pontianak Class II Port Authority and Authority. These two variables are contrary to research conducted by Fida et al. (2020). But the results are in accordance with the research conducted by Gopi and Samat (2020).

Partially the empathy variable has a $t$ value of 0.763 which is smaller than the t table $\alpha 0.05$, then $0.763>1.665$. So it can be concluded that this research variable empathy partially has no significant effect on customer satisfaction at PT. Port of Pontianak Class II Port Authority and Authority. These variables are opposite to investigate carried out by Fida et al. (2020). But the results are in accordance with the research conducted by Gopi and Samat (2020).

Multiple linear regression analysis is used to determine how much influence the independent variable (X) which consists of Tangible / Physical Evidence (X1), Reliability (X2), Responsiveness (X3), Assurance (X4), and Empathy / Empathy (X5) towards the dependent variable (Y), namely Customer Satisfaction (Situmorang and Lutfi, 2012: 146).

\section{CONCLUSION}

Based on the data in Table 8 , the multiplelinear regression equationmodelcan be formulated as follows: $\mathrm{Y}=3,947+0,268 \mathrm{X} 1+0,193 \mathrm{X} 2-$ $0,009 \times 3+0,321 \mathrm{X} 4+0,077 \mathrm{X} 5$

From this equation it can be described: (i) Constant $=3,947$. This shows a constant level, where if the Tangible (X1), Reliability (X2), Responsiveness (X3), Assurance (X4) and Empathy (X5) variables are 0, then customer satisfaction (Y) on the Port Authority and Port Authority services Class II Pontianak amounted to 3,947. (ii) The coefficient $\mathrm{b} 1(\mathrm{X} 1)=0.268$. This shows that the Tangible variable (X1) has a positive effect on Customer Satisfaction, or in other words, if the Tangible variable is increased, then the customer satisfaction of the Port Authority and Port Authority of Class II Pontianak will increase by 0.268 assuming the 
other variables are fixed. (iii) The coefficient b2 $(\mathrm{X} 2)=0.193$. This shows that the Reliability (X2) variable does not have a significant effectonCustomer Satisfaction, or in other words, if the Reliability variable increases, then the customer satisfaction has no effect. (iv) The coefficient b3 (X3) $=-0.009$. This shows that the Responsiveness variable (X3) does not have a significant effecton Customer Satisfaction, or in other words, if the Responsiveness variable increases, then the customer satisfaction has no effect. (v) The coefficient b4 (X4) = 0.321. This shows that the Assurance variable (X4) has a positive effect on Customer Satisfaction, or in other words, if the Assurance variable increases, then the customer satisfaction of the Port Authority and Port Authority of Class II Pontianak will increase by 0.321 assuming other variables remain. (vi) The coefficient of b5 (X5) $=0.077$. This shows that the Empathy variable (X5) does not have a significant effecton Customer Satisfaction, or in other words, if the Empathy variable increases, then the customer satisfaction has no effect.

\section{REFERENCES}

AFTHANORHAN, A., AWANG, Z., RASHID, N., FOZIAH, H. \& GHAZALI, P. L. 2019. Assessing the effects of service quality on customer satisfaction. Management Science Letters, 13-24.

ALAM, M. M. D. \& NOOR, N. A. M. 2020. The Relationship Between Service Quality, Corporate Image, and Customer Loyalty of Generation Y: An Application of S-O-R Paradigm in the Context of Superstores in Bangladesh. SAGE Open, 10, 215824402092440.

ARIKUNTO, S. 2006. Prosedur Penelitian: Suatu Pendekatan Praktik. Edisi Revisi VI, Jakarta, Rineka Cipta.

BHATT, K. 2020. Measuring service fairness and its impact on service quality and satisfaction: a study of Indian Banking Services. Journal of Financial Services Marketing, 25, 35-44.

CARUANA, A., MONEY, A. H. \& BERTHON, P. R. 2020. Service Quality and Satistaction - The Moderating Role Of Value. European Journal of Marketing, 34, 1338-1352.

CHIKAZHE, L., MAKANYEZA, C. \& KAKAVA, N. Z. 2020. The effect of perceived service quality, satisfaction and loyalty on perceived job performance: perceptions of university graduates. Journal of Marketing for Higher Education, 1-18.

DE LEON, M. V., ATIENZA, R. P., SUSILO, D. \& WRIGHT, L. T. 2020. Influence of self-service technology (SST) service quality dimensions as a second-order factor on perceived value and customer satisfaction in a mobile banking application. Cogent Business \& Management, 7, 1794241. 
EKAABI, M., KHALID, K., DAVIDSON, R. \& NONINO, F. 2020. The service quality and satisfaction of smart policing in the UAE. Cogent Business \& Management, 7, 1751904.

FERDINAND, A. 2006. Metode Penelitian Manajemen: Pedoman Penelitian untuk Penulisan Skripsi, Tesis dan Desertasi, Semarang, Badan Penerbit Universitas Diponegoro.

FIDA, B. A., AHMED, U., AL-BALUSHI, Y. \& SINGH, D. 2020. Impact of Service Quality on Customer Loyalty and Customer Satisfaction in Islamic Banks in the Sultanate of Oman. SAGE Open, 10, 215824402091951.

GOPI, B. \& SAMAT, N. 2020. The influence of food trucks' service quality on customer satisfaction and its impact toward customer loyalty. British Food Journal, 122, 3213-3226.

KARSONO 2007. Peran Variabel dan Citra Perusahaan, Kepercayaan, dan Biaya Perpindahan yang Memediasi Pengaruh Kualitas Pelayanan terhadap Loyalitas Pelanggan, Jakarta, Gramedia Pustaka Utama.

KHATOON, S., ZHENGLiANG, X. \& HUSSAIN, H. 2020. The Mediating Effect of Customer Satisfaction on the Relationship Between Electronic Banking Service Quality and Customer Purchase Intention: Evidence From the Qatar Banking Sector. SAGE Open, 10, 215824402093588.

KOTLER, P. \& KELLER, K. L. 2008. Manajemen Pemasaran (edisi 13), Jakarta, Erlangga.

LE, D. N., NGUYEN, H. T. \& HOANG TRUONG, P. 2020. Port logistics service quality and customer satisfaction: Empirical evidence from Vietnam. The Asian Journal of Shipping and Logistics, 36, 89-103.

NAIK, C. N. K., GANTASALA, S. B. \& PRABHAKAR, G. V. 2010. Service Quality (Servqual) and its Effect on Customer Satisfaction in Retailing. European Journal of Social Sciences, 16, 239-251.

NUNKOO, R., TEEROOVENGADUM, V., RINGLE, C. M. \& SUNNASSEE, V. 2020. Service quality and customer satisfaction: The moderating effects of hotel star rating. International Journal of Hospitality Management, 91, 102414.

ÖZKUL, E., BILGILI, B. \& KOÇ, E. 2020. The Influence of the color of light on the customers' perception of service quality and satisfaction in the restaurant. Color Research \& Application, 45, 1217-1240. 
PARASURAMAN, A. P., ZEITHAML, V. A. \& BERRY, L. L. 1988. SERVQUAL: A multiple- Item Scale for measuring consumer perceptions of service quality. Journal of Retailing, 64, 12-40.

PENA, M. M., DA SILVA, E. M., TRONCHIN, D. M. \& MELLEIRO, M. M. 2013. [The use of the quality model of Parasuraman, Zeithaml and Berry in health services]. Rev Esc Enferm USP, 47, 1235-40.

PRENTICE, C., DOMINIQUE LOPES, S. \& WANG, X. 2020. The impact of artificial intelligence and employee service quality on customer satisfaction and loyalty. Journal of Hospitality Marketing \& Management, 29, 739-756.

SUGIYONO 2004. Metode Penelitian, Bandung, Alfabeta.

SUGIYONO 2007. Metodologi Penelitian Bisnis, Jakarta, Gramedia.

SUPRANTO 2001. Pengukuran Tingkat Kepuasan Pelanggan untuk Menaikkan Pangsa Pasar, Jakarta, Rineka Cipta.

TJIPTONO, F. 2006. Manajemen jasa, Yogyakarta, Andi.

TJIPTONO, F. 2008. Strategi Pemasaran, Yogyakarta, Andi.

TUNCER, I., UNUSAN, C. \& COBANOGLU, C. 2020. Service Quality, Perceived Value and Customer Satisfaction on Behavioral Intention in Restaurants: An Integrated Structural Model. Journal of Quality Assurance in Hospitality \& Tourism, 1-29. 